\title{
The Association Between the Physical Environment of Primary Schools and Active School Transport
}

Citation for published version (APA):

van Kann, D. H. H., Kremers, S. P. J., Gubbels, J. S., Bartelink, N. H. M., de Vries, S. I., de Vries, N. K., \& Jansen, M. W. J. (2015). The Association Between the Physical Environment of Primary Schools and Active School Transport. Environment and Behavior, 47(4), 418-435.

https://doi.org/10.1177/0013916513519644

Document status and date:

Published: 01/01/2015

DOI:

10.1177/0013916513519644

Document Version:

Publisher's PDF, also known as Version of record

Document license:

Taverne

Please check the document version of this publication:

- A submitted manuscript is the version of the article upon submission and before peer-review. There can be important differences between the submitted version and the official published version of record.

People interested in the research are advised to contact the author for the final version of the publication, or visit the DOI to the publisher's website.

- The final author version and the galley proof are versions of the publication after peer review.

- The final published version features the final layout of the paper including the volume, issue and page numbers.

Link to publication

\footnotetext{
General rights rights.

- You may freely distribute the URL identifying the publication in the public portal. please follow below link for the End User Agreement:

www.umlib.nl/taverne-license

Take down policy

If you believe that this document breaches copyright please contact us at:

repository@maastrichtuniversity.nl

providing details and we will investigate your claim.
}

Copyright and moral rights for the publications made accessible in the public portal are retained by the authors and/or other copyright owners and it is a condition of accessing publications that users recognise and abide by the legal requirements associated with these

- Users may download and print one copy of any publication from the public portal for the purpose of private study or research.

- You may not further distribute the material or use it for any profit-making activity or commercial gain

If the publication is distributed under the terms of Article $25 \mathrm{fa}$ of the Dutch Copyright Act, indicated by the "Taverne" license above, 


\title{
The Association Between the Physical Environment of Primary Schools and Active School Transport
}

Environment and Behavior 2015, Vol. 47(4) 4I8-435

(C) 2014 SAGE Publications

Reprints and permissions: sagepub.com/journalsPermissions.nav DOI: 10.1177/0013916513519644 eab.sagepub.com

@SAGE

\author{
D. H. H. Van Kann 1,3, S. P. J. Kremers', J. S. \\ Gubbels $^{2}$, N. H. M. Bartelink ${ }^{3}$, S. I. de Vries ${ }^{4,5}$, N. \\ K. de Vries ${ }^{1,3}$, and M. W. J. Jansen ${ }^{3,6}$
}

\begin{abstract}
This study examined the relationship between the physical environment characteristics of primary schools and active school transport among 3,438 5- to 12-year-old primary school children in the Netherlands. The environmental characteristics were categorized into four theory-based clusters (function, safety, aesthetics, and destination). The correlations between the clusters and active school transport were examined, and multilevel regression analyses were used to examine the association between the clusters and active school transport. No correlations were found between environmental clusters and active school transport for younger children (age 5-9), but for older children (age 9-12), strong positive correlations were found between aesthetics and active transport as were found for safety and active transport. School neighborhood aesthetics were
\end{abstract}

\footnotetext{
'Maastricht University, Health Promotion, CAPHRI, Maastricht, The Netherlands 2Maastricht University, Health Promotion, NUTRIM, Maastricht, The Netherlands ${ }^{3}$ Academic Collaborative Center for Public Health Limburg, Geleen, The Netherlands ${ }^{4}$ TNO, Expertise Center LifeStyle, Leiden, The Netherlands ${ }^{5}$ The Hague University of Applied Science, The Netherlands ${ }^{6}$ Maastricht University, Health Services Research, CAPHRI, Maastricht, The Netherlands
}

\section{Corresponding Author:}

Dave Van Kann, School for Public Health and Primary Care (CAPHRI), Department of Health Promotion, Faculty of Health, Medicine, and Life Sciences, Maastricht University, P.O. Box 616, 6200 MD, Maastricht, The Netherlands.

Email: d.vankann@maastrichtuniversity.nl 
related to active transport for older primary school children. Presence of parks, good maintenance of green spaces, and absence of litter in the school environment contributed most to the positive association between aesthetics and active school transport.

\section{Keywords}

active school transport, primary school, physical environment, aesthetics, safety

\section{Introduction}

The prevalence of overweight and obesity is rapidly increasing among children, leading to physical problems such as Type II diabetes and cardiovascular diseases in later life (Andersen et al., 2006) as well as psycho-social problems such as being teased and lower self-esteem (Biddle, Gorely, \& Stensel, 2004). Since overweight and physical inactivity patterns formed in childhood are major predictors of overweight in adulthood (Singh, Mulder, Twisk, Van Mechelen, \& Chinapaw, 2008), special attention should be devoted to the prevention and treatment of childhood overweight. Nevertheless, time spent in physical inactivity and sedentary behavior is increasing worldwide (Kohl et al., 2012; Mitchell, Pate, Beets, \& Nader, $2013)$. In the Netherlands, only $30 \%$ to $40 \%$ of the children meet the recommended 60 daily minutes of moderate-to-vigorous physical activity (De Vries $\&$ Chorus, 2010; World Health Organization, 2010), and these proportions are even lower for children living in deprived neighborhoods (de Vries et al., 2005; Uiters \& Verweij, 2010; Van Lenthe, Brug, \& Mackenbach, 2005).

Active school transport (AST; e.g., walking and cycling) can make a major contribution to daily physical activity and to the development of active lifestyle patterns (Cooper, Jago, Southward, \& Page, 2012; Faulkner, Buliung, Flora, \& Fusco, 2009; Owen, Humpel, Leslie, Bauman, \& Sallis, 2004; Panter, Jones, \& van Sluijs, 2008; Rennie, Johnson, \& Jebb, 2005; van Sluijs et al., 2009). However, a decreasing proportion of children are using active transport, which is being replaced by motorized transportation to school (McDonald, 2007; Salmon, Timperio, Telford, Carver, \& Crawford, 2005; van der Ploeg, Merom, Corpuz, \& Bauman, 2008). A range of possible determinants has contributed to the increased use of motorized school transport. Increased prosperity has led to an increased number of families that could afford owning a car and consequently make these people able to choose for motorized school transport. Furthermore, the perceived convenience of driving to school could have contributed to the decrease in active transportation 
(Trapp et al., 2011). Moreover, environmental characteristics (both physical and social) are likely to be important in determining this behavior, so identification of environmental correlates is essential to help reverse the downward trend (Panter et al., 2008; Tudor-Locke, Ainsworth, \& Popkin, 2001). Several studies (McMillan, 2007; Timperio et al., 2006) showed that the use of AST is inhibited by unsafe local neighborhoods, due to factors like traffic (e.g., busy roads, high traffic density) and social hazards (e.g., stranger danger and crime), while the distance to one's destination has also been found to be a major predictor of active transport use (McDonald, 2007; McMillan, 2007). Walking and cycling infrastructures, such as sidewalks and cycling paths, have also been reported to be environmental correlates of AST (Kerr et al., 2006).

Neighborhood characteristics can be structured and classified using socioecological models (Kremers et al., 2006; Pikora, Giles-Corti, Bull, Jamrozik, \& Donovan, 2003). Pikora et al.'s (2003) framework distinguishes four main environmental clusters related to walking and cycling in the local neighborhood. These neighborhood characteristics are clustered into function (e.g., physical attributes of the built environment), safety (e.g., social and traffic safety), aesthetics (e.g., access to interesting and pleasant physical environments), and destination (e.g., availability of community or commercial facilities in the neighborhood). Assembling the neighborhood characteristics into these theory-based clusters might be useful for understanding the local aspects associated with school transport.

The present cross-sectional study used Pikora's clustered approach to study the association between the school environment and the use of active transport to school among 5- to 12-year-old Dutch primary school children. This study focused on deprived areas, mostly inhabited by people in vulnerable positions and by children who were not fulfilling the recommended daily amount of physical activity (Uiters \& Verweij, 2010).

\section{Method}

\section{Description of Research Population}

This study focused on children from 19 primary schools situated in neighborhoods with a low socio-economic status (LSES) in five municipalities (i.e., Heerlen, Sittard-Geleen, Maastricht, Kerkrade, and Meerssen) in Southern Limburg, the Netherlands. School size ranged from 64 to 311 students. Children were between 5 and 12 years old, distributed over 8 grades (years). This study took place within the academic collaborative center for public health Limburg in which the local municipalities, public health services, and 
university work together intensively. The schools were invited by the local public health services to participate in this study, using mail and phone calls. The schools were asked to give permission for on-site visits to assess the number of children using active transport to come to school that day.

\section{Instruments}

AST use was determined by visiting each grade of the participating schools (Grades 1 to 8), and asking the children "How did you come to school this morning?" (by car/by bike/on foot/other). Final scores were reported as $1=$ active travel, that is, by bike and on foot or $0=$ motorized travel, that is, by car and other. Children responded by raising their hands. The results were summarized for each school and grade into percentages of children using active versus motorized school transport. Children who were too young to cycle themselves, but were taken on their parents' bike, were counted as active travelers, whereas children who arrived on the back of their parents' scooter or motorcycle were categorized as motorized travelers. The transportation mode of a total of 3,438 children was established. None of the children refused to answer.

Characteristics of the physical environment were scored for a $400 \mathrm{~m}$ radius around all participating schools, using the "Environmental Scan for Active Transport to School" (ESATS; Online Appendix 1). The ESATS is based on the Spatial Planning and Children's Exercise (SPACE) checklist (De Vries, Hopman-Rock, Bakker, Hirasing, \& Van Mechelen, 2010), which is a Dutch version of the Neighborhood Environment Walkability Scale (NEWS; Saelens, Sallis, Black, \& Chen, 2003). The NEWS has been adapted to correct for differences in the American and Dutch physical environment. Subsequently, the SPACE-checklist was adapted to record characteristics specifically related to active transport. In addition, a geographical adjustment (the presence of hills; Timperio et al., 2006) was made in the checklist, as this was specifically relevant for the current study area of Southern Limburg, resulting in ESATS. Presence of hills was included because they could be perceived as barrier for active transport. In our study sample, as is typical for the Dutch context, but even more typical for the study area of South Limburg, primary schools were covering a relatively small service area in homogeneous neighborhoods within the $400 \mathrm{~m}$ buffer of each school (Figure 1). Although a pivotal focus has been paid to the physical environment of schools, generally a significant proportion of children's route to school as well as home neighborhood of children were included in the school neighborhood environmental audits. 


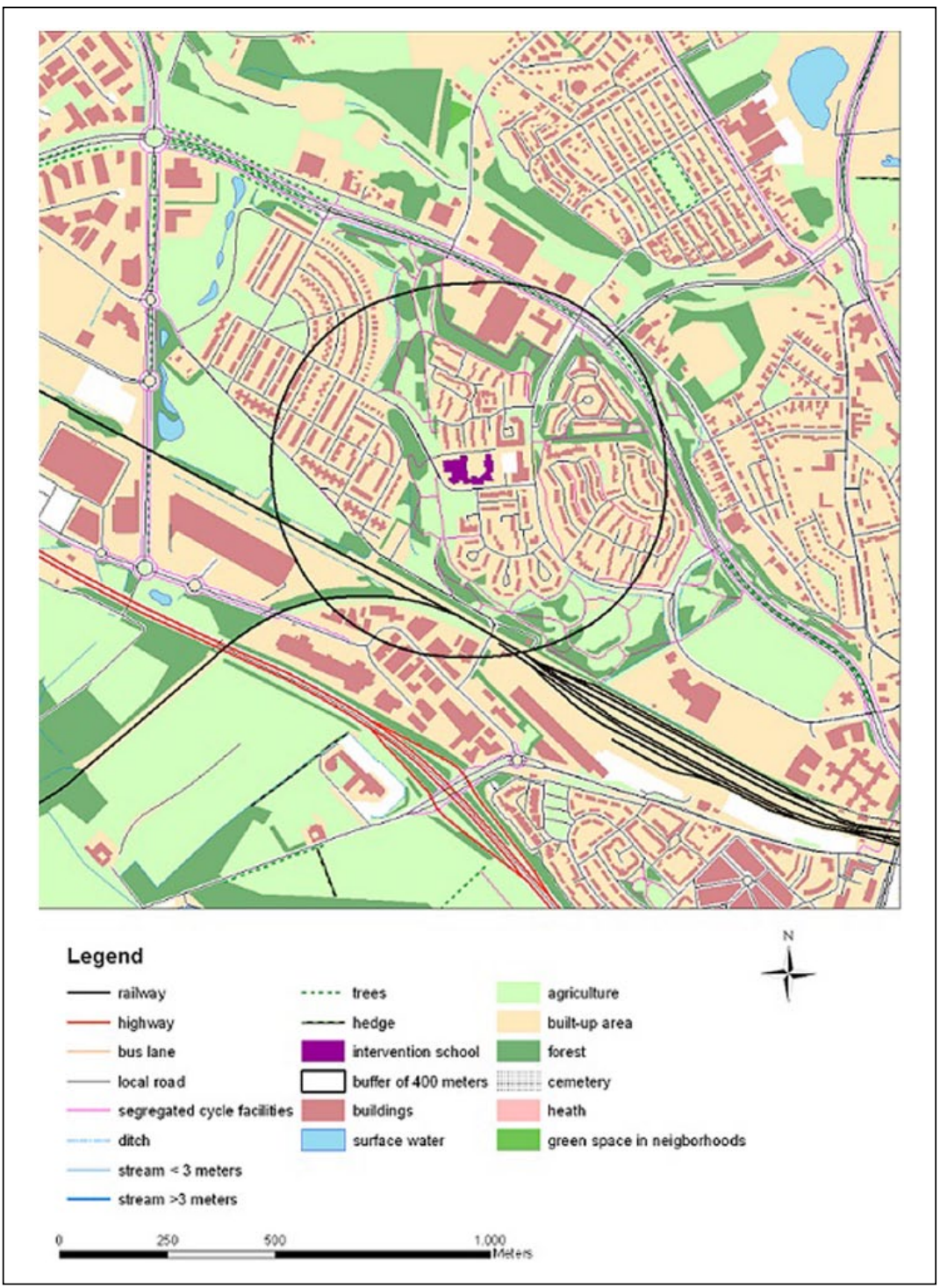

Figure I. Example school neighborhood environment, $400 \mathrm{~m}$ buffer.

Four clusters were created within the ESATS, based on the framework of physical environment factors by Pikora and colleagues: functional features (possible cluster score range: 0-73; e.g., of an item: presence of cycling 
Table I. Demographics and Active Transport Use (Total and Stratified) Per School.

\begin{tabular}{|c|c|c|c|c|c|}
\hline School & Municipality & SES score ${ }^{b}$ & $\%$ AST $(N)$ & $\begin{array}{c}\text { \% AST grades } \\
\text { I-5 (N) }\end{array}$ & $\begin{array}{c}\% \text { AST } \\
\text { Grades 6-8 } \\
(N)\end{array}$ \\
\hline I & I & -2.31 & $71.2(146)$ & $64.6(96)$ & $84.0(50)$ \\
\hline 2 & 2 & -2.69 & $73.4(64)$ & $65.8(38)$ & $84.6(26)$ \\
\hline 3 & 3 & -1.91 & $52.3(130)$ & $45.9(85)$ & $64.4(45)$ \\
\hline 4 & I & -2.31 & 76.5 (I53) & $71.0(93)$ & $85.0(60)$ \\
\hline 5 & I & -2.31 & $67.8(311)$ & $66.1(186)$ & $70.4(125)$ \\
\hline 6 & 1 & -2.08 & 57.9 (297) & $54.8(188)$ & $63.3(109)$ \\
\hline 7 & I & -2.08 & $73.8(84)$ & $64.6(48)$ & $86.1(36)$ \\
\hline 8 & I & -1.97 & $48.7(196)$ & $46.8(124)$ & $51.4(72)$ \\
\hline 9 & I & -1.54 & $74.1(166)$ & $70.5(95)$ & 78.9 (7I) \\
\hline 10 & 2 & -1.44 & 59.1 (154) & $47.8(90)$ & $75.0(64)$ \\
\hline II & 2 & -1.44 & $69.9(236)$ & $65.2(164)$ & $80.6(72)$ \\
\hline 12 & 4 & -2.11 & $58.8(294)$ & $48.4(2 \mid 3)$ & $86.4(81)$ \\
\hline 13 & 5 & -0.46 & $66.9(133)$ & $61.7(81)$ & $75.0(52)$ \\
\hline 14 & 3 & -1.37 & 77.7 (103) & $76.3(76)$ & $81.5(27)$ \\
\hline 15 & I & -1.55 & 48.3 (207) & 42.1 (133) & $59.5(74)$ \\
\hline 16 & 5 & -0.46 & $72.5(167)$ & 69.4 (III) & $78.6(56)$ \\
\hline 17 & 4 & -2.11 & $47.3(182)$ & 44.1 (I I8) & $53.1(64)$ \\
\hline 18 & 3 & -1.83 & $59.6(188)$ & 56.1 (139) & $69.4(49)$ \\
\hline 19 & 3 & -1.13 & $67.8(227)$ & $63.0(138)$ & $75.3(89)$ \\
\hline Total & & & $63.9(3438)$ & $59.2(234 I)$ & 73.8 (1097) \\
\hline
\end{tabular}

Note. SES = socio-economic status; AST = active school transport; $N=$ number of children. aMunicipalities; I = Heerlen, 2 = Sittard-Geleen, 3 = Maastricht, 4 = Kerkrade, 5 = Meerssen. bSES score (ranging from -4 to +4 ) indicates the socio-economic status of the local neighborhood.

paths), safety features ( $0-42$; e.g., presence of crossing aids), aesthetic features (0-29; e.g., presence of parks), and destination features (0-36; e.g., presence of bicycle sheds at school). Clusters were assembled by a theory-driven approach. The theory-based clusters were all correlated $<.7$ with each other (Table 1), i.e. each cluster explains less than half of the variance of another cluster.

Two observers assessed the school neighborhood environments. Each audit was performed by similar conditions in April 2011 during school hours. The audits took place within 2 weeks with comparable weather conditions; dry days with temperatures ranging from $11^{\circ} \mathrm{C}$ to $21^{\circ} \mathrm{C}$. Each scan took about 
90 min to complete, and both assessors walked and cycled around the school areas to get a general impression of walkability and cycle-friendliness. Differences between the observers' scores were solved by discussion to reach consensus immediately after the observations took place. Reassessment of disputable characteristics was possible by immediate discussion of the observers' scores.

An socio-economic status (SES) score was calculated for each school, indicating the SES of the neighborhood in which the school is located. This score ranges from -4 (extremely deprived) to +4 (extremely well-off) and is based on mean household income, percentages of households with low income, percentages of residents without paid work, and percentages of households with a low educational level on average (Knol, 2012).

\section{Statistical Analyses}

Data were analyzed using SPSS, version 19.0 (SPSS Inc., Chicago). First, differences in use of active transport between lower grades ( 1 to 5 ) and higher grades (6 to 8 ) were assessed by an independent $t$-test because differences in these subgroups were expected (Timperio et al., 2006). If a grade-related difference in AST was found, a dichotomous variable was constructed to discriminate between lower grades, in which school transport under parental supervision is likely, and higher grades. Associations between the ESATS clusters and active transport, for the entire sample as well as for both subgroups, were examined by calculating Pearson's correlation coefficients.

Multilevel regression analyses with two levels (school level and child level) were then conducted to examine the association between active transport and the ESATS clusters. We used backward deletion for the least significant cluster in each model, and the final model only contained statistically significant clusters $(p<.05)$. We also examined the intra-class correlation (ICC), which reflects the proportion of the total variation in active transport that is explained by the final model.

Subsequently, in-depth analyses of significant clusters in the final model were used to examine the associations between the individual characteristics included in the cluster and the use of AST. Similar to the analyses with ESATS clusters, two-level logistic multilevel regression analyses were performed, with all individual characteristics within the particular cluster as independent variables and AST as dependent variable, using the backward procedure.

\section{Results}

The 19 participating primary schools had a SES score varying between -0.5 (slightly deprived neighborhood) and -2.7 (highly deprived neighborhood). 
Table 2. Pearson's Correlations ( $r$ ) Between ESATS Clusters, SES Score, and AST at School Level $(N=19)$.

\begin{tabular}{|c|c|c|c|c|c|c|c|c|}
\hline & 1 & 2 & 3 & 4 & 5 & 6 & 7 & 8 \\
\hline I. Function & & $.64 * *$ & .20 & .42 & .28 & .28 & .22 & .29 \\
\hline 2. Safety & & & $.58^{* *}$ & $.48^{*}$ & -.18 & .37 & .25 & $.47 *$ \\
\hline 3. Aesthetics & & & & $.68 * *$ & -.37 & .40 & .32 & $.54 *$ \\
\hline 4. Destination & & & & & .15 & .13 & .03 & .41 \\
\hline 5. SES score & & & & & & -.14 & -.18 & -.02 \\
\hline 6. AST Grades I-8 & & & & & & & & \\
\hline 7. AST Grades I-5 & & & & & & & & \\
\hline 8. AST Grades 6-8 & & & & & & & & \\
\hline
\end{tabular}

Note. SES score (range -0.464 to -2.688 ); ESATS = Environmental Scan for Active Transport to School; SES = socio-economic status; AST = active school transport.

$*_{p}<.05 .{ }^{* *} p<.01$.

The average number of children enrolled at each school was $181(S D=69.3$; Table 1).

Percentages of children traveling to school using active transport varied between $47.3 \%$ and $77.7 \%$ per school, with an average of $59.2 \%$ in the lower grades (1-5) and $73.8 \%$ in the higher grades $(6-8), t(2438)=8.30, p<.01$. Of the children who used AST ( $n=2,170 ; 64.4 \%), 27.0 \%$ cycled to school $(n=$ $585)$ and $73.0 \%$ walked to school $(n=1,585)$.

Table 2 presents the correlations between all ESATS clusters, SES scores, and active transport at school level. Statistically significant positive correlations were found between safety and all other ESATS clusters, and between the aesthetic and destination clusters. Furthermore (although non-significant), SES was negatively correlated with local aesthetics and safety but positively with function and destination.

All associations (except for SES) found between the school environment and AST were positive, that is, physical environment scores were positively correlated with active transport. A positive association between aesthetics and active transportation, as well as for safety and active transportation, was found for the higher grades.

A moderating effect of lower and higher grades was found on the association between aesthetics and active transport (interaction term; $B=.083, p<$ .01 ), so we performed two separate multilevel regression analyses for the subgroups. For children in the lower grades, all ESATS clusters were removed from the regression equation in the final model, indicating that none of the environmental clusters were associated with active transport. For children in the higher grades, aesthetics was significantly associated with active 
Table 3. Stratified Multilevel Regression Analyses for ESATS Clusters and SES Score for Active School Transport (AST).

\begin{tabular}{|c|c|c|c|c|c|c|c|c|}
\hline & \multicolumn{4}{|c|}{ Grades I-5 $(N=234 \mathrm{I})$} & \multicolumn{4}{|c|}{ Grades 6-8 $(N=1097)$} \\
\hline & \multicolumn{2}{|c|}{ Full model } & \multicolumn{2}{|c|}{ Final modela } & \multicolumn{2}{|c|}{ Full model } & \multicolumn{2}{|c|}{ Final model $^{\mathrm{a}}$} \\
\hline & B & $p$ & $B$ & $p$ & B & $p$ & B & $p$ \\
\hline ESATS function & .04 & .26 & & & -.01 & .75 & & \\
\hline ESATS safety & -.03 & .60 & & & .07 & .39 & & \\
\hline ESATS aesthetics & .08 & .14 & .03 & .21 & .10 & .13 & .09 & $<.01$ \\
\hline ESATS destination & -.06 & .20 & & & -.02 & .67 & & \\
\hline SES score & .01 & .97 & & & -.03 & .30 & & \\
\hline
\end{tabular}

Note. ESATS = Environmental Scan for Active Transport to School; SES = socio-economic status.

aVariables excluded using backward deletion for the least significant variable in each models.

transport in the final model (Table 3). The odds ratio (OR) was 1.09 (95\% CI $=[1.03,1.15)$, which means that the likelihood of active transport increased by $9 \%$ for each point of increase in the aesthetic cluster score. The proportion of the total variance (ICC) of active transport explained by aesthetics was $7 \%$.

In-depth analyses within the aesthetic cluster showed that the presence of a park within the school neighborhood environment was the strongest correlate of active transport for children in the higher grades $(\mathrm{OR}=1.32,95 \% \mathrm{CI}$ $=[1.09,1.54], p=.02)$. In addition, the absence of litter on streets in the school environment was positively associated with active transport $(\mathrm{OR}=$ $1.61,95 \% \mathrm{CI}=[1.17,2.06], p=.03)$, as was good maintenance of local green spaces in this environment $(\mathrm{OR}=2.07,95 \% \mathrm{CI}=[1.43,2.72], p=.04)$.

\section{Discussion}

The current study examined the association between school neighborhood environment characteristics and the use of active transport by primary school children in the Netherlands. A total of $63.9 \%$ of the children in our sample used active transport, with higher proportions of older children doing so. School neighborhood characteristics were not found to be associated with active transport to school among young children, which is in line with studies conducted by Carver and colleagues (Carver, Timperio, \& Crawford, 2008; Carver, Timperio, Hesketh, \& Crawford, 2010). They found environmental correlates of active transport only among older children. This might be 
explained by the dependence of this age group on the parents (Panter et al., 2008). Young children are mostly unable to travel to school by themselves, due to restrictions imposed by their parents or insufficient cycling or walking skills (Carver, Watson, Shaw, \& Hillman, 2013; Hume et al., 2009). A recent study by Carver showed that older children were licensed more frequently to use independent mobility to school, and this license was positively associated with active transport (Carver et al., 2013). Parents are the main decision makers regarding the mode of transportation to school, and their environmental determinants of active transport use are likely to differ from the children's (Faulkner, Richichi, Buliung, Fusco, \& Moola, 2010; Panter et al., 2008; Timperio, Crawford, Telford, \& Salmon, 2004). For instance, time constraints may mean that parents are more inclined to use a car as a transportation method, regardless of environmental features around the school (Ahlport, Linnan, Vaughn, Evenson, \& Ward, 2008; Nelson, Foley, O'Gorman, Moyna, $\&$ Woods, 2008). Trapp and colleagues (Trapp et al., 2011) found that the likelihood of active transport decreased when parents perceived driving their child to school to be more convenient, which implies that social determinants may be more important than physical environmental factors in predicting the use of active transport by younger children.

The strongest positive correlation between school neighborhood environment and active transport of older children was found for aesthetics. This implies that the attractiveness of the school neighborhood environment may influence the mode of transportation. An aesthetically more attractive environment has previously been found to relate to increased levels of physical activity (Veitch et al., 2011). In-depth analyses of the aesthetic cluster in our study showed that it was particularly the presence of a park in the school environment that was associated with active transport. Internationally, the presence of parks has mainly been associated with increased recreational physical activity (Cohen et al., 2007). In the Dutch school context, the presence of parks (or trails in parks) could be considered an important correlate of active transport. This finding is in line with the new urbanism philosophy of Calthorpe (1993), who endorses the creation of small neighborhood parks that provide diverse and pleasant scenery on route. Observational data do not suggest any destination effect of the presence of parks in school environmental neighborhood with regard to active transport, which endorses the urbanism philosophy that the pleasant scenery can contribute to this behavior. Good maintenance of local green spaces was also associated with active transport in line with the review by Lee \& Maheswaran (2011), who found that issues of maintenance affect the appeal of green spaces. The use or nonuse of green spaces not only depends on its features but also on their condition. Another aesthetic characteristic that was positively associated with 
active transport was the absence of litter. Sugiyama and colleagues (Sugiyama, Leslie, Giles-Corti, \& Owen, 2009) found that the attractiveness of the environment, including the absence of litter, was positively associated with walking by adults. The presence of litter has also been found to be negatively correlated with trail use (Reynolds et al., 2007). Both maintenance of local green spaces and absence of litter are contributing to pleasant scenery. Although it may be quite challenging to increase the number of parks within a densely populated residential area, the other two aesthetic environmental correlates, maintenance of local green spaces and absence of litter, may be less challenging to improve in school neighborhood environments, for instance, by municipal regulations.

In addition to the importance of local aesthetic characteristics, we found a strong positive correlation between local safety and active transport use by older schoolchildren. Safety issues include mainly traffic safety and also social safety such as vandalism. Traffic hazards, such as dangerous intersections and the lack of speed limits, have previously been reported by parents as a major barrier preventing them from giving their children permission to go to school on foot or by bike (Carver et al., 2010; Timperio et al., 2006; Weir, Etelson, \& Brand, 2006). Timperio et al. (2006) also found that increased traffic density is an important aspect of traffic safety and is a barrier to active transport.

In our multilevel regression analyses, the safety cluster was not significantly associated with active transport. However, in view of the strong correlation between safety and active transport, this does not imply that safety issues are unimportant, but its associative value might be less than in other international studies (e.g., in the United States and Australia), because several safety-related characteristics are present in almost all school neighborhood environments in the Netherlands, even in deprived areas (e.g., sidewalks, cycling paths, crossing guards, pedestrian crossings). The presence of such safety features in all school neighborhood environments may explain why we found relatively little variance within this cluster. Our findings can be interpreted on the basis of the hierarchical framework proposed by Alfonzo (Alfonzo, 2005). A certain threshold of safety characteristics in the school environment is an essential condition for the use of active transportation. Once these safety requirements are fulfilled, the aesthetic features of the school neighborhood environment might become more important correlates of active transport use. Other potentially important explanatory factors might be parental beliefs about AST or perceived health effects of active transportation.

Strong aspects of the present study include its sample size as well as the inclusion of children living in deprived areas. Compared to non-deprived 
areas, deprived areas are generally characterized by fewer features promoting physical activity and increased incivilities (Lee, Booth, Reese-Smith, Regan, $\&$ Howard, 2005) as well as worse aesthetics, such as lower ratings of maintenance and decreased visual quality (Zhu \& Lee, 2008) that could decrease physical activity, including active transport. Furthermore, a variety of school neighborhood environments were included, which resulted in adequate variance between school neighborhood environments. The clustered and multilevel analytic approach also provided added value, although the multilevel approach simultaneously limited the level-two variance to 19 school neighborhood environments.

A limitation is the assessment of active transport use, which was done by asking children to report their mode of transportation in class. Although De Wit, Loman, Faithfull, \& Hinckson (2012) recently argued the validity of this method of collecting data, it may have led to social desirability bias. However, we have no indication that the children were pressured or biased to answer this question dishonestly. With regard to the assessment of active transport, it should be noted that a distinction was made between active and motorized transport. This implies that children that were brought to school by bike by their parents, but were not bicycling themselves, were calculated as active travelers. This classification was underpinned by the strength of parental modeling behavior. It was expected that children whose parents use active transport to bring their child to school are likely to use active transport themselves when being physically able to travel independently (Murtangh, Rowe, Elliott, McMinn, \& Nelson, 2012). Due to the focus on age-related associations between the physical school neighborhood environment and AST, other demographic variables, such as gender, have not been included in the datagathering process. Another shortcoming is that we were unable to calculate the distance between the children's home and school, since we were not able to track the addresses of the participating children. Distance can be a major barrier to active transport (Panter et al., 2008; Pont, Ziviani, Wadley, Bennett, \& Abbott, 2009) and the lack of this information could, therefore, have affected the associations we found between local school environment and active transport. However, this barrier is probably not as influential as it is in studies from other countries, as Dutch children generally live within a short distance $(600 \mathrm{~m})$ of schools (Centraal Bureau voor de Statistiek, 2012), a circumstance that may be considered favorable for active transport. Due to the proximity of primary schools in the Netherlands, most children typically go to the nearest primary school (Bekkers, de Kool, \& Straten, 2012). Finally, a more detailed focus on all three environmental components of AST (school environment, route, and home environment) would be more informative compared to combining those components in school neighborhood environments. For this a more fine-grained instrument is needed than the 
ESATS-checklist, as well as the use of other network buffers and additional global positioning system (GPS)- and geographic information system (GIS)-data.

\section{Conclusion}

The association between local school neighborhood environment and the use of AST differed for younger and older Dutch primary school children. Associations between environmental features and AST were only found for older children, probably because younger children depend on their parents for transportation. Aesthetic and safety features in the school neighborhood environment were correlated with the use of AST among children aged 9 to 12 years. Factors especially associated with the use of active transportation by children included aesthetic characteristics, such as the presence of parks, good maintenance of green spaces, and absence of litter on the streets in the school environment, and these could, therefore, be regarded as potential aspects to intervene on.

\section{Acknowledgment}

We are grateful to the schools and children participating in this study.

\section{Declaration of Conflicting Interests}

The author(s) declared no potential conflicts of interest with respect to the research, authorship, and/or publication of this article.

\section{Funding}

The author(s) disclosed receipt of the following financial support for the research, authorship, and/or publication of this article: The study was funded by the Netherlands Organization for Health Research and Development (ZonMW), project number 200130003.

\section{References}

Ahlport, K. N., Linnan, L., Vaughn, A., Evenson, K. R., \& Ward, D. S. (2008). Barriers to and facilitators of walking and bicycling to school: Formative results from the non-motorized travel study. Health Education \& Behavior, 35, 221-244. doi: $10.1177 / 1090198106288794$

Alfonzo, M. A. (2005). To walk or not to walk? The hierarchy of walking needs. Environment and Behavior, 37, 808-836. doi:10.1177/0013916504274016

Andersen, L. B., Harro, M., Sardinha, L. B., Froberg, K., Ekelund, U., Brage, S., \& Anderssen, S. A. (2006). Physical activity and clustered cardiovascular risk in 
children: A cross-sectional study (The European Youth Heart Study). The Lancet, 368, 299-304.

Bekkers, V. J. J. M., de Kool, D., \& Straten, G. F. M. (2012). Educational Governance: Strategie, ontwikkeling en effecten [Educational Governance: Strategy, development, and effects] (NWO/Beleidsgericht Onderzoek Primair Onderwijs). Rotterdam: Erasmus University Rotterdam, Netherlands Institute of Government.

Biddle, S. J. H., Gorely, T., \& Stensel, D. J. (2004). Health-enhancing physical activity and sedentary behaviour in children and adolescents. Journal of Sports Sciences, 22, 679-701. doi:10.1080/02640410410001712412

Calthorpe, P. (1993). The next American metropolis: Ecology, community, and the American dream. Princeton, NJ: Princeton University Press.

Carver, A., Timperio, A., \& Crawford, D. (2008). Neighborhood road environments and physical activity among youth: The CLAN study. Journal of Urban Health, $85,532-544$.

Carver, A., Timperio, A., Hesketh, K., \& Crawford, D. (2010). Are safety-related features of the road environment associated with smaller declines in physical activity among youth? Journal of Urban Health, 87, 29-43. doi:10.1007/s11524009-9402-3

Carver, A., Watson, B., Shaw, B., \& Hillman, M. (2013). A comparison study children's independent mobility in England and Australia. Children's Geographies, 11, 461-475. doi:10.1080/1733285.2013.2812303

Centraal Bureau voor de Statistiek. (2012). Nabijheid voorzieningen; afstand tot locatie, regionaal. [Nearness of amenities; distance to location, regional]. Den Haag, The Netherlands: Author.

Cohen, D. A., McKenzie, T. L., Sehgal, A., Williamson, S., Golinelli, D., \& Lurie, N. (2007). Contribution of public parks to physical activity. American Journal of Public Health, 97, 509-514. doi:10.2105/ajph.2005.072447

Cooper, A. R., Jago, R., Southward, E. F., \& Page, A. S. (2012). Active travel and physical activity across the school transition: The PEACH project. Medicine \& Science in Sports \& Exercise, 44, 1890-1897. doi:10.1249/MSS.0b013e31825a3a1e

De Vries, S. I., Bakker, I., Van Overbeek, K., Boer, N., Hopman-Rock, M., \& Jeugd, P. (2005). Kinderen in prioriteitswijken: Lichamelijke (in)activiteit en overgewicht [Children in deprived neighborhoods: Physical activity or inactivity and overweight]. Leiden, The Netherlands: TNO Kwaliteit van Leven.

De Vries, S. I., \& Chorus, A. M. J. (2010). Bewegen in Nederland: Jeugdigen van 4-17 jaar [Physical activity in the Netherlands: Youngsters aged 4-17 years]. In V. H. Hildebrandt, A. M. J. Chorus, \& J. H. Stubbe (Eds.), TNO Trendrapport Bewegen en Gezondheid (pp. 57-76). Leiden, The Netherlands: De Bink.

De Vries, S. I., Hopman-Rock, M., Bakker, I., Hirasing, R. A., \& Van Mechelen, W. (2010). Built environmental correlates of walking and cycling in Dutch urban children: Results from the SPACE study. International Journal of Environmental Research and Public Health, 7, 2309-2324.

De Wit, B., Loman, K., Faithfull, K., \& Hinckson, E. A. (2012). Reliability and validity of the hands-up survey in assessing commuting to school in New 
Zealand elementary school children. Health Promotion Practice, 13, 349-354. doi: $10.1177 / 1524839911432932$

Faulkner, G. E. J., Buliung, R. N., Flora, P. K., \& Fusco, C. (2009). Active school transport, physical activity levels and body weight of children and youth: A systematic review. Preventive Medicine, 48, 3-8.

Faulkner, G. E. J., Richichi, V., Buliung, R., Fusco, C., \& Moola, F. (2010). What's "quickest and easiest?" Parental decision making about school trip mode. International Journal of Behavioral Nutrition and Physical Activity, 7, Article 62.

Hume, C., Timperio, A., Salmon, J., Carver, A., Giles-Corti, B., \& Crawford, D. (2009). Walking and cycling to school: Predictors of increases among children and adolescents. American Journal of Preventive Medicine, 36, 195-200. doi:10.1016/j.amepre.2008.10.011

Kerr, J., Rosenberg, D., Sallis, J. F., Saelens, B. E., Frank, L. D., \& Conway, T. L. (2006). Active commuting to school: Associations with environment and parental concerns. Medicine \& Science in Sports \& Exercise, 38, 787-794. doi:10.1249/01. mss.0000210208.63565.73

Knol, F. (2012). Statusontwikkeling van wijken in Nederland 1998-2010 [Status development of neighbourhoods in the Netherland 1998-2010]. The Hague: The Netherlands Institute for Social Research [SCP].

Kohl, H. W., Craig, C. L., Lambert, E. V., Inoue, S., Alkandari, J. R., Leetongin, G., \& Kahlmeier, S. (2012). The pandemic of physical inactivity: Global action for public health. The Lancet, 380, 294-305. doi:10.1016/S0140-6736(12)60898-8

Kremers, S. P., de Bruijn, G. J., Visscher, T. L., van Mechelen, W., de Vries, N. K., \& Brug, J. (2006). Environmental influences on energy balance-related behaviors: A dual-process view. International Journal of Behavioral Nutrition and Physical Activity, 3, 9.

Lee, A. C. K., \& Maheswaran, R. (2011). The health benefits of urban green spaces: A review of the evidence. Journal of Public Health, 33, 212-222. doi:10.1093/ pubmed/fdq068

Lee, R. E., Booth, K. M., Reese-Smith, J. Y., Regan, G., \& Howard, H. H. (2005). The Physical Activity Resource Assessment (PARA) instrument: Evaluating features, amenities and incivilities of physical activity resources in urban nieghborhoods. International Journal of Behavioral Nutrition and Physical Activity, 2, Article 13.

McDonald, N. C. (2007). Active transportation to school: Trends among U.S. schoolchildren, 1969-2001. American Journal of Preventive Medicine, 32, 509-516.

McMillan, T. E. (2007). The relative influence of urban form on a child's travel mode to school. Transportation Research Part A: Policy and Practice, 41, 69-79.

Mitchell, J. A., Pate, R. R., Beets, M. W., \& Nader, P. R. (2013). Time spent in sedentary behavior and changes in childhood BMI: A longitudinal study from ages 9 to 15 years. International Journal of Obesity, 37, 54-60.

Murtangh, S., Rowe, D. A., Elliott, M. A., McMinn, D., \& Nelson, N. M. (2012). Predicting active school travel: The role of planned behavior and habit strength. International Journal of Behavioral Nutrition and Physical Activity, 9, 65. 
Nelson, N. M., Foley, E., O’Gorman, D. J., Moyna, N. M., \& Woods, C. B. (2008). Active commuting to school: How far is too far? International Journal of Behavioral Nutrition and Physical Activity, 5, 1.

Owen, N., Humpel, N., Leslie, E., Bauman, A., \& Sallis, J. F. (2004). Understanding environmental influences on walking: Review and research agenda. American Journal of Preventive Medicine, 27, 67-76.

Panter, J., Jones, A., \& van Sluijs, E. (2008). Environmental determinants of active travel in youth: A review and framework for future research. International Journal of Behavioral Nutrition and Physical Activity, 5, 34.

Pikora, T., Giles-Corti, B., Bull, F., Jamrozik, K., \& Donovan, R. (2003). Developing a framework for assessment of the environmental determinants of walking and cycling. Social Science \& Medicine, 56, 1693-1703.

Pont, K., Ziviani, J., Wadley, D., Bennett, S., \& Abbott, R. (2009). Environmental correlates of children's active transportation: A systematic literature review. Health \& Place, 15, 849-862.

Rennie, K. L., Johnson, L., \& Jebb, S. A. (2005). Behavioural determinants of obesity. Best Practice \& Research: Clinical Endocrinology \& Metabolism, 19, 343-358.

Reynolds, K. D., Wolch, J., Byrne, J., Chou, C.-P., Feng, G., Weaver, S., \& Jerrett, M. (2007). Trail characteristics as correlates of urban trail use. American Journal of Health Promotion, 21, 335-345.

Saelens, B. E., Sallis, J. F., Black, J. B., \& Chen, D. (2003). Neighborhood-based differences in physical activity: An environmental scale evaluation. American Journal of Public Health, 93, 1552-1558.

Salmon, J., Timperio, A., Telford, A., Carver, A., \& Crawford, D. (2005). Association of family environment with children's television viewing and with low level of physical activity. Obesity Research, 13, 1939-1951.

Singh, A. S., Mulder, C., Twisk, J. W. R., Van Mechelen, W., \& Chinapaw, M. J. M. (2008). Tracking of childhood overweight into adulthood: A systematic review of the literature. Obesity Reviews, 9, 474-488. doi:10.1111/j.1467789X.2008.00475.x

Sugiyama, T., Leslie, E., Giles-Corti, B., \& Owen, N. (2009). Physical activity for recreation or exercise on neighbourhood streets: Associations with perceived environmental attributes. Health \& Place, 15, 1058-1063. doi:10.1016/j.healthplace.2009.05.001

Timperio, A., Ball, K., Salmon, J., Roberts, R., Giles-Corti, B., Simmons, D., . . .Crawford, D. (2006). Personal, family, social, and environmental correlates of active commuting to school. American Journal of Preventive Medicine, 30, 45-51.

Timperio, A., Crawford, D., Telford, A., \& Salmon, J. (2004). Perceptions about the local neighborhood and walking and cycling among children. Preventive Medicine, 38, 39-47.

Trapp, G. S. A., Giles-Corti, B., Christian, H. E., Bulsara, M., Timperio, A. F., McCormack, G. R., \& Villanueva, K. P. (2011). Increasing children's physical activity: Individual, social, and environmental factors associated with walking to and from school. Health Education \& Behavior. Advance online publication. doi:10.1177/1090198111423272 
Tudor-Locke, C., Ainsworth, B. E., \& Popkin, B. M. (2001). Active commuting to school: An overlooked source of children's physical activity? Sports Medicine, 31, 309-313.

Uiters, E., \& Verweij, A. (2010). Lichamelijke activiteit: Zijn er verschillen in sociaaleconomische status? [Physical activity: Are there differences in socio-economic status?]. Bilthoven, The Netherlands: Volksgezondheid Toekomst Verkenning, Nationaal Kompas Volksgezondheid, RIVM.

van der Ploeg, H. P., Merom, D., Corpuz, G., \& Bauman, A. E. (2008). Trends in Australian children traveling to school 1971-2003: Burning petrol or carbohydrates? Preventive Medicine, 46, 60-62.

Van Lenthe, F. J., Brug, J., \& Mackenbach, J. P. (2005). Neighbourhood inequalities in physical inactivity: The role of neighbourhood attractiveness, proximity to local facilities and safety in the Netherlands. Social Science \& Medicine, 60, 763-775.

van Sluijs, E. M. F., Fearne, V. A., Mattocks, C., Riddoch, C., Griffin, S. J., \& Ness, A. (2009). The contribution of active travel to children's physical activity levels: Cross-sectional results from the ALSPAC study. Preventive Medicine, 48, 519524.

Veitch, J., Timperio, A., Crawford, D., Abbott, G., Giles-Corti, B., \& Salmon, J. (2011). Is the neighbourhood environment associated with sedentary behaviour outside of school hours among children? Annals of Behavioral Medicine, 41, 333-341. doi:10.1007/s12160-011-9260-6

Weir, L. A., Etelson, D., \& Brand, D. A. (2006). Parents' perceptions of neighborhood safety and children's physical activity. Preventive Medicine, 43, 212-217. doi:10.1016/j.ypmed.2006.03.024

World Health Organization. (2010). Global recommendations on physical activity for health. Geneva, Switzerland: WHO Press.

Zhu, X. M., \& Lee, C. (2008). Walkabiltiy and safety around elementary schools: Economic and ethnic disparities. American Journal of Preventive Medicine, 34, 282-290.

\section{Author Biographies}

D. H. H. Van Kann, MSc, is pursuing his PhD within the School for Public Health and Primary Care (CAPHRI) in the Department of Health Promotion at Maastricht University. His research focuses on the effects of the physical and social environment on physical activity of children.

S. P. J. Kremers, $\mathrm{PhD}$, is a professor in obesity prevention at the Department of Health Promotion, Nutrition, and Toxicology at Research Institute Maastricht (NUTRIM). His research focuses on the study of determinants of weight gain and on the systematic development of weight-gain prevention programs for different target groups.

J. S. Gubbels, $\mathrm{PhD}$, is a post-doctoral researcher at the Department of Health Promotion, Nutrition, and Toxicology at Research Institute Maastricht (NUTRIM). 
Her research focuses on environmental influence on nutrition and physical activity of preschool children.

N. H. M. Bartelink, MSc, graduated from Maastricht University in 2011, specializing in master in sports and physical activity interventions. Currently, she is working as a researcher at the Public Health Services South-Limburg, the Netherlands.

S. I. de Vries, $\mathrm{PhD}$, was a researcher and project manager at TNO Department of Healthy Living and is currently working as a professor in healthy lifestyle at The Hague University of Applied Sciences. Her research focuses on the relationship between built environment and physical activity, and she is specialized in using accelerometers.

N. K. de Vries, $\mathrm{PhD}$, is a professor in the Department of Health Promotion and chair of the School for Public Health and Primary Care (CAPHRI), Maastricht University. His research focuses on theory and practice in health promotion with a special emphasis on determinants and change of nonreasoned behaviors.

M. W. J. Jansen, $\mathrm{PhD}$, is the chair of the Academic Collaborative Center for Public Health Limburg, the Netherlands. Her research focuses on interdisciplinary collaborations and the integration of research, policy, and practice. 